\title{
Pine Wood Particles Pyrolysis and Radiographic Analysis
}

\section{Piroliza čestica borovine i radiološka analiza}

\author{
Original scientific paper • Izvorni znanstveni rad \\ Received-prispjelo: 7. 8. 2018. \\ Accepted-prihvaćeno: 20. 11. 2019. \\ UDK: $630 * 812.463 ; 630 * 813.4$ \\ https://doi.org/10.5552/drvind.2020.1834
}

\author{
CC 2020 by the author(s). \\ Licensee Faculty of Forestry, University of Zagreb. \\ This article is an open access article distributed \\ under the terms and conditions of the \\ Creative Commons Attribution (CC BY 4.0) license.
}

\begin{abstract}
The goal of this experiment is to assess the mass and volume loss of medium size pine wood particles undergoing pyrolysis. Wood samples of different sizes and shapes were pyrolysed at $500{ }^{\circ} \mathrm{C}$ with different residence times. A thermogravimetric analysis was carried out for comparison purposes. Finally, the pyrolysed samples were analysed using radiographic methods. A connection between the different analyses was found. For larger particles, the heating rate is lower, and a time gap between hemicellulose and cellulose thermal decomposition was noticed. Research shows that an important part of the analysis of the process is the rate of biomass heating and sample size. As the sample size increases, the pyrolysis time increases; however, the increase is not linear. The publication also shows the great possibilities of radiographic methods in analysing the pyrolysis process.
\end{abstract}

Key words: pyrolysis; biomass; thermogravimetric analysis; radiography; heat transfer

SAŽETAK • Cilj istraživanja bio je procijeniti gubitak mase i volumena čestica borovine srednje veličine podvrgnutih pirolizi. Uzorci drva različitih veličina i oblika pirolizirani su pri $500{ }^{\circ} \mathrm{C}$ i pri različitim vremenima trajanja pirolize. Za usporedbu je provedena termogravimetrijska analiza borovih čestica. Nakon toga pirolizirani su uzorci analizirani metodom radiografije. Pronađena je veza između različitih analiza. Brzina zagrijavanja većih čestica je niža, a primijećen je i vremenski jaz između toplinskog raspadanja hemiceluloze i celuloze. Istraživanja su pokazala da su važan dio analize procesa pirolize brzina zagrijavanja biomase i veličina uzorka. Kako se veličina uzorka povećava, tako se povećava $i$ vrijeme pirolize, $i$ to nelinearno. Usto, rad upućuje na velike mogućnosti radiografskih metoda $u$ analizi procesa pirolize.

Ključne riječi: piroliza; biomasa; termogravimetrijska analiza; radiografija; prijenos topline

\section{INTRODUCTION 1. UVOD}

Nowadays, efforts can be seen all around the globe in the direction of gaining autonomy and independence from fossil fuels, pursuing a decrease on greenhouse gas emissions and more sustainable energy future. A possible path is the use of solid biomass, which can be pyrolysed or gasified, either alone or coprocessed with coal.

Pyrolysis is the thermal decomposition of organic matter in the absence of oxygen, with temperatures ranging from $200{ }^{\circ} \mathrm{C}$ to $600{ }^{\circ} \mathrm{C}$. Chemical compounds are decomposed into lighter ones due to several reactions mostly of endothermic nature. The products of pyrolysis are char, bio-oil and gas, the quality and quantity of each product produced being highly influenced by the temperature, residence time, heating rate and size and shape of the particle.

Wood biomass is composed of three main components: lignin, cellulose and hemicellulose. Hemicellulose is the first to be decomposed, between 200 and $250^{\circ} \mathrm{C}$. Cellulose breaks down in temperatures ranging from 240 to $350{ }^{\circ} \mathrm{C}$ (Czajczyńska et al., 2017). Both

\footnotetext{
${ }^{1}$ Authors are researchers at Institute of Fluid Flow Machinery, Polish Academy of Sciences, Gdańsk, Poland.

${ }^{2}$ Author is MSc Student at AGH University of Science and Technology, Kraków, Poland.
} 
hemicellulose and cellulose are decomposed in mild pyrolysis, also known as torrefaction. Lignin requires higher temperatures, from 280 up to $500{ }^{\circ} \mathrm{C}$ (Demirbas, 2014; Shi and Wang, 2014). Since it does not break down to lighter molecular weight compounds easily, lignin is the main component of char (Lu et al., 2018).

Three main kinds of reactors can be used to perform pyrolysis: fixed bed, fluidised bed and entrained flow. Fixed bed reactors are of simpler design and cheaper production, however they have a limited application. Technical issues, such as bridging and jamming of biomass, make this kind of reactor unsuitable for alternative kinds of biomass and waste (Pham et al., 2018). Pelletizing can be a solution to this constraint (Erlich and Fransson, 2011). Since regular wood biomass does not lead to these inconvenient situations, it can easily be used in fixed bed reactors.

Being pyrolysis one of the first phases in gasification, and the one in which the mass decreases the most and the velocity consequently increases, an empirical understanding of the particles behaviour under such conditions would allow a better design of gasification chambers.

\section{MATERIALI AND METHODS}

\section{MATERIJALI I METODE}

Pine wood samples of a different kind were prepared, with different sizes and shapes. Cubes were of 20 mm side, larger cubes of $30 \mathrm{~mm}$ side, parallelepipeds of $20 \times 20 \times 5 \mathrm{~mm}$, cylinders with $27 \mathrm{~mm}$ of diameter and 35 $\mathrm{mm}$ height and finally cylinders with $20 \mathrm{~mm}$ of diameter and $5 \mathrm{~mm}$ height. When it comes to the parallelepipeds, some of them were cut perpendicular to the grain, whilst the others were cut parallel to the grain.

First, the samples were placed at $500{ }^{\circ} \mathrm{C}$ for different residence times, ranging from $30 \mathrm{~s}$ to $960 \mathrm{~s}$, depending on the actual situation. Nitrogen was used to provide an oxygen-free environment to the reaction chamber. A schematic of the experimental setting can be seen in Figure 1.

The accurate dimensions of each sample were measured and registered before the experiment, as well as their mass. Finally, the samples were weighted and measured again, in order to analyse the pyrolysis effect on them. The final shape of the sample would no longer be a regular one, but it was considered as so, taking the biggest possible measure into consideration. Concerning the cylinders, their base was considered as an ellipse. Mass and volume losses were calculated, as well as the density and its variation.

Lately, a thermogravimetric analysis was performed using an SDT Q600 analyser. The argon flow rate was $100 \mathrm{~mL} / \mathrm{min}$ and the heating rate $100 \mathrm{~K} / \mathrm{min}$, which heated the sample up to $800^{\circ} \mathrm{C}$.

Finally, the samples were submitted to X-ray, in order to analyse the pyrolysis effect on its inner structure. Radiographic techniques are commonly used in areas like Chemical Analysis, its non-destructive nature being one of its biggest advantages. That being said, this method allows to observe the internal struc-

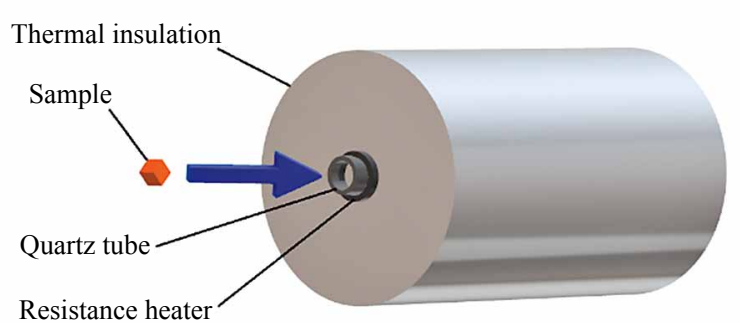

Figure 1 Schematic representation of the pyrolysis chamber used for the experiment

Slika 1. Shematski prikaz komore za pirolizu rabljene u pokusu

ture of a sample without interfering with it, offering information of the effect of temperature and residence time of pyrolysis in a sample structure. Further ahead, the possibility of analysing the samples via X-ray whilst being pyrolysed inside the chamber could come to life, as a monitoring tool. The use of radiographic techniques is widely spread in science and technology, but the use of these methods to study pyrolysis is not common. It is a technique with large potential in basic research to better understand the pyrolysis process.

\section{RESULTS}

\section{REZULTATI}

\subsection{Momentary comparison}

3.1. Trenutačna usporedba

The mass, volume and density variations after pyrolysis at $500{ }^{\circ} \mathrm{C}$ were compared for different kinds of samples at equal residence times (Figures 2-7). The mass loss was calculated by equation 1 , and volume loss in a similar way. It is to be noticed that one single comparison between all kinds of samples was not possible, due to different residence time intervals tested for each shape.

$$
\text { mass } \operatorname{loss}(\%)=\frac{m_{\text {initial }}-m_{\text {final }}}{m_{\text {initial }}} \times 100 \%
$$

It is quite visible that the smaller the sample, the higher will be the mass loss for equal residence times. When it comes to volume, the results are more irregular, but apart from the parallelepipeds cut perpendicular to the grain, the volume decrease is also lower for smaller samples. Finally, a similar situation can be seen for density variations: the smaller the sample, the more it changes.

\subsection{Evolutive comparison}

\subsection{Naknadna usporedba}

The ratio between the mass after pyrolysis and the initial one was plotted against residence time. As expected, the bigger the sample the longer it takes for it to be pyrolysed, since the heat transfer is more difficult for these cases.

\subsection{Thermogravimetric analysis}

3.3. Termogravimetrijska analiza

A thermogravimetric analysis was carried out for a sample weighting $5.1570 \mathrm{mg}$ of pine wood, of the same origin as the tested samples. 


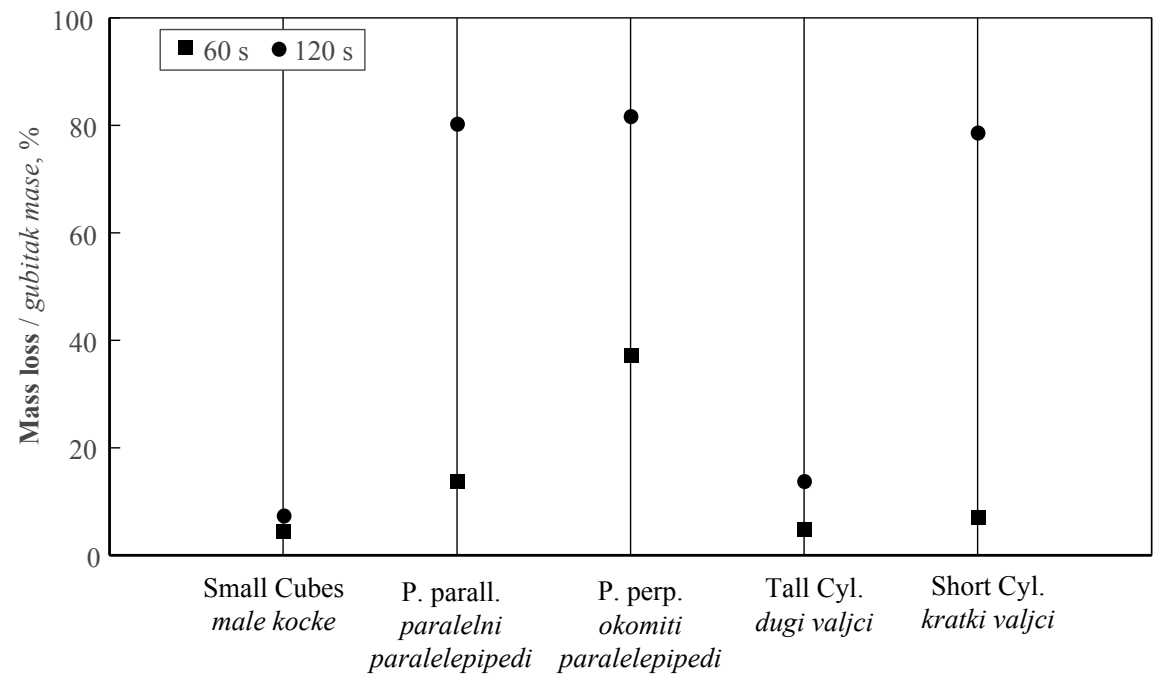

Figure 2 Comparison of mass loss at $60 \mathrm{~s}$ and $120 \mathrm{~s}$ for different shapes

Slika 2. Usporedba gubitka mase pri pirolizi od 60 i $120 \mathrm{~s}$ za čestice različitog oblika

There are three main slopes in the TGA curve (fig. 8). The first one, around $100{ }^{\circ} \mathrm{C}$, refers to the moisture release, due to water evaporation. The second one, between $300{ }^{\circ} \mathrm{C}$ and $400{ }^{\circ} \mathrm{C}$, is associated to hemicellulose and cellulose degradation. After $400{ }^{\circ} \mathrm{C}$ the curve's slope is softer since only lignin is decomposed. At $700^{\circ} \mathrm{C}$, the sample is already completely pyrolysed.

Since the heating rate was $100 \mathrm{~K} / \mathrm{min}$, the curves turning point at $400{ }^{\circ} \mathrm{C}$ corresponds to a residence time of $240 \mathrm{~s}$.

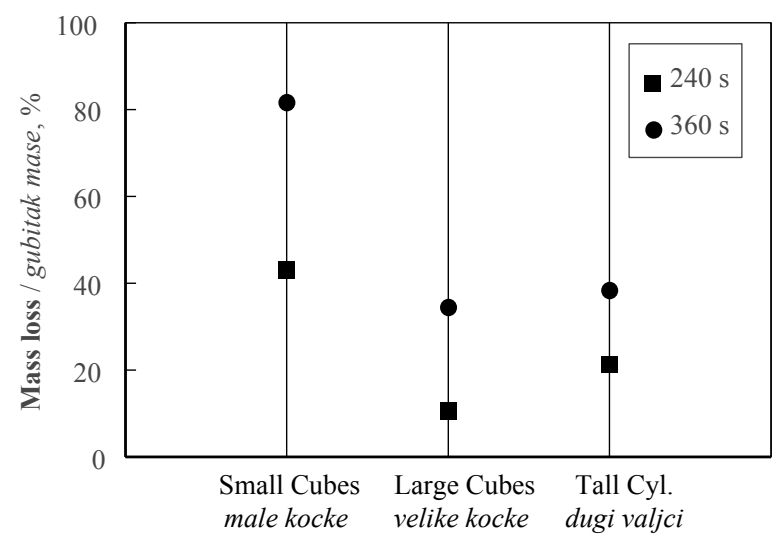

Figure 3 Comparison of mass loss at $240 \mathrm{~s}$ and $360 \mathrm{~s}$ for different shapes

Slika 3. Usporedba gubitka mase pri pirolizi od 240 i $360 \mathrm{~s}$ za čestice različitog oblika

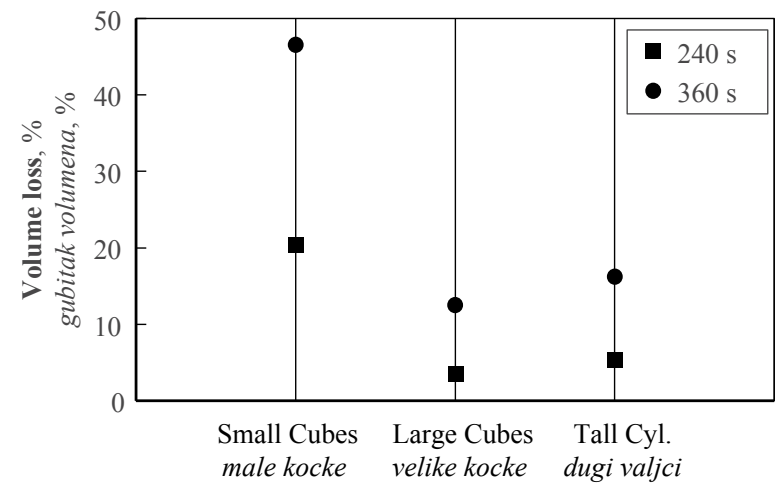

Figure 5 Volume loss at $240 \mathrm{~s}$ and $360 \mathrm{~s}$ for different shapes Slika 5. Gubitak volumena pri pirolizi od 240 i 360 s za čestice različitog oblika

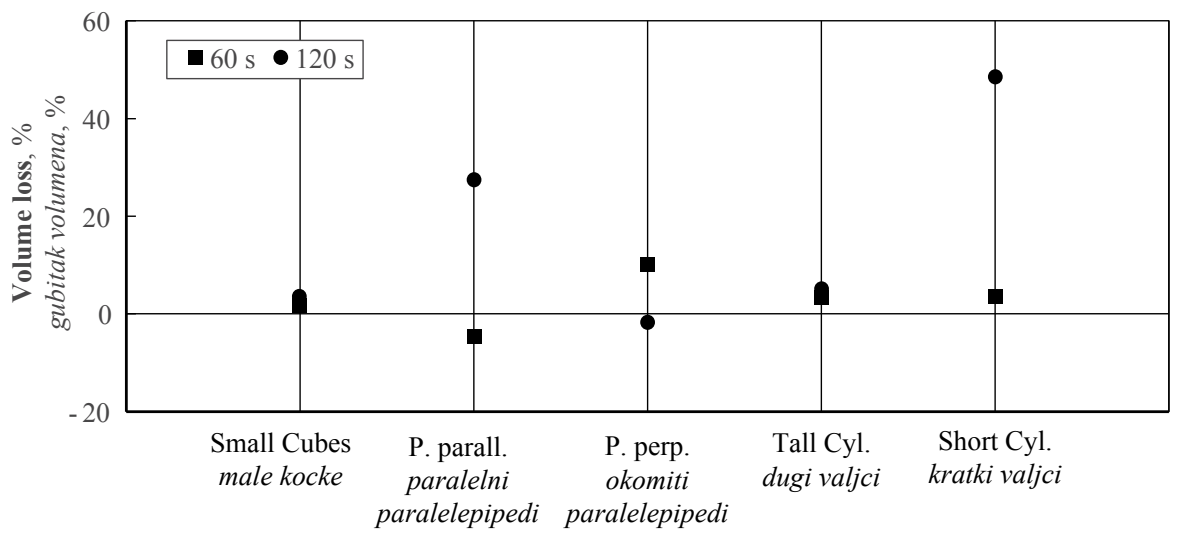

Figure 4 Volume loss at $60 \mathrm{~s}$ and $120 \mathrm{~s}$ for different samples

Slika 4. Gubitak volumena pri pirolizi od 60 i 120 s za čestice različitog oblika 


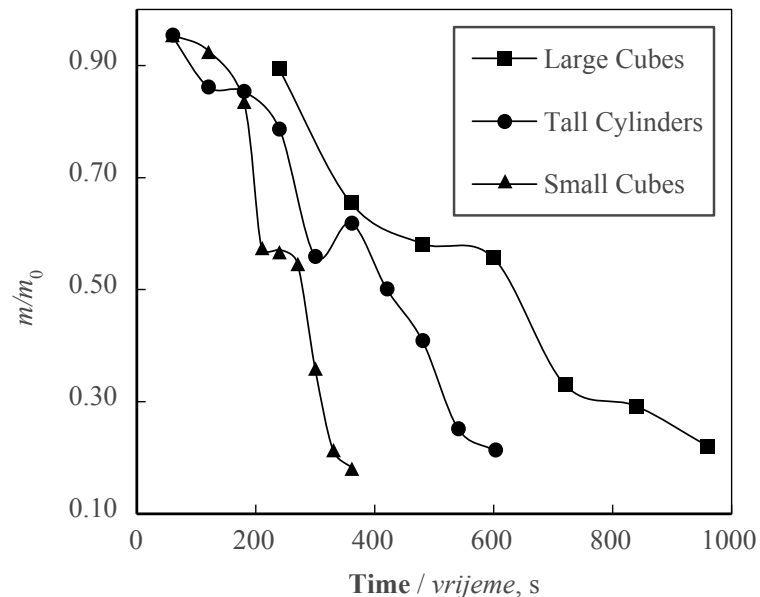

Figure 6 Ratio between final and initial mass versus residence time for larger samples

Slika 6. Odnos konačne i početne mase u ovisnosti o trajanju pirolize za velike uzorke

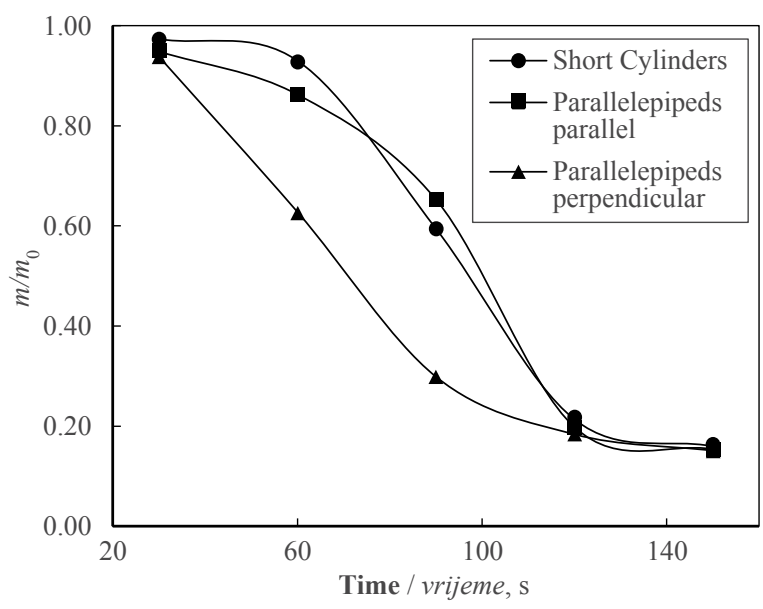

Figure 7 Ratio between final and initial mass versus residence time for smaller samples

Slika 7. Odnos konačne i početne mase u ovisnosti o trajanju pirolize za male uzorke

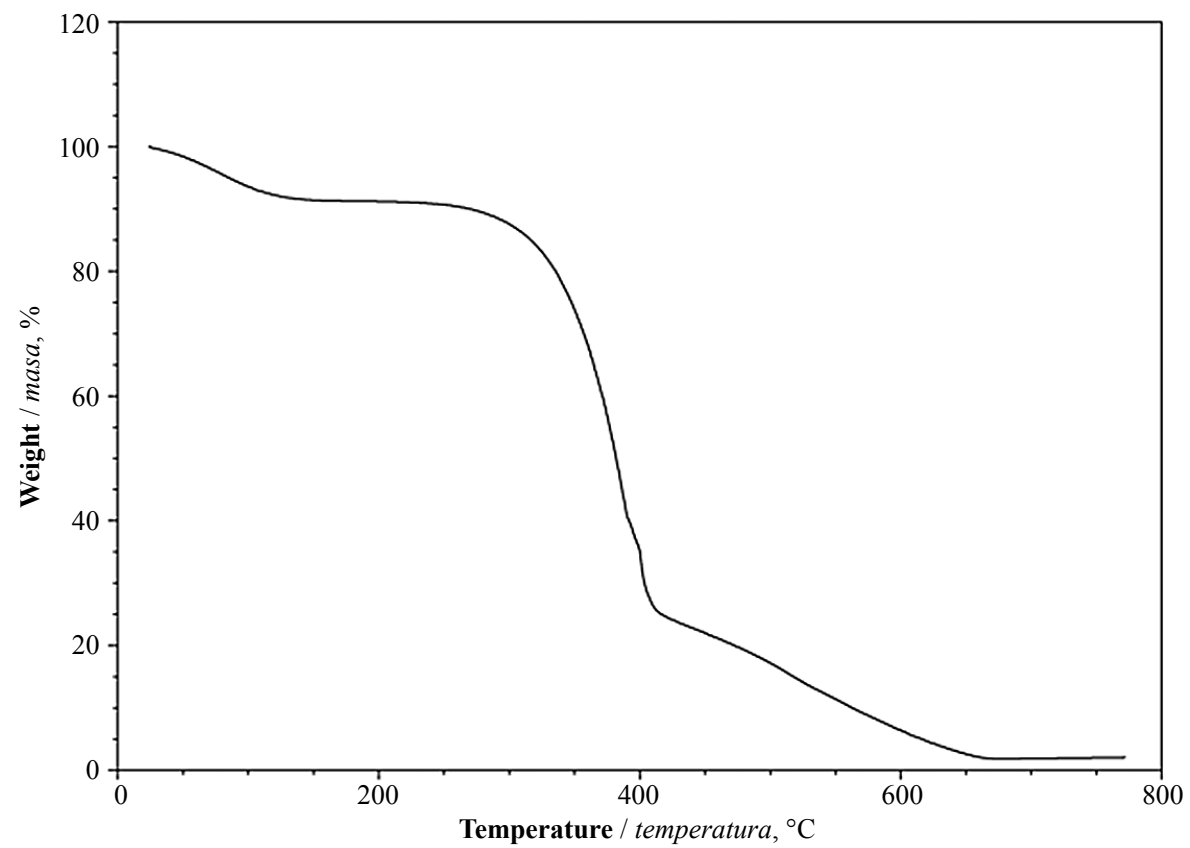

Figure 8 Thermogravimetric analysis of pine wood with an argon flow of $100 \mathrm{~mL} / \mathrm{min}$ and heating rate of $100 \mathrm{~K} / \mathrm{min}$, from 0 to $800{ }^{\circ} \mathrm{C}$

Slika 8. Termogravimetrijska analiza borovine od 0 do $800{ }^{\circ} \mathrm{C}$, pri protoku argona od $100 \mathrm{~mL} / \mathrm{min}$ i pri brzini zagrijavanja od $100 \mathrm{~K} / \mathrm{min}$

\subsection{Radiographic Analysis}

3.4. Radiografska analiza

The pyrolysed samples were exposed to X-ray with the following results:

As expected, the more pyrolysed the sample, the darker it is, since the density is lower. It is worth notic-

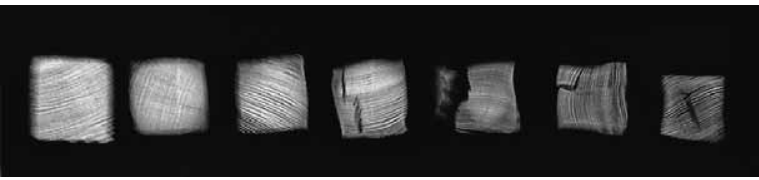

Figure 9 Radiographic images from larger cubic samples (30 mm side) after pyrolysis at $500{ }^{\circ} \mathrm{C}$. From left to right: $240 \mathrm{~s}, 360 \mathrm{~s}, 480 \mathrm{~s}, 600 \mathrm{~s}, 720 \mathrm{~s}, 840 \mathrm{~s}$ and $920 \mathrm{~s}$

Slika 9. Rendgenske snimke uzoraka kocaka većih stranica $(30 \mathrm{~mm})$ nakon pirolize pri $500{ }^{\circ} \mathrm{C}$; slijeva nadesno: nakon $240 \mathrm{~s}, 360 \mathrm{~s}, 480 \mathrm{~s}, 600 \mathrm{~s}, 720 \mathrm{~s}, 840 \mathrm{~s}$ i $920 \mathrm{~s}$ ing that, when the samples crack, the crack's direction is perpendicular to the grain, as can be seen in Figure 9. Also, both in Figures 9 and 10, a lighter circle can be seen in the third sample counting from the right. This happens due to the higher exposure of the corners, which leads to their faster thermal degradation.

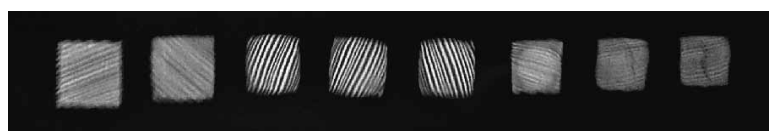

Figure 10 Radiographic images from smaller cubic samples (20 mm side) after pyrolysis at $500{ }^{\circ} \mathrm{C}$. From left to right: 60 s, $120 \mathrm{~s}, 180 \mathrm{~s}, 210 \mathrm{~s}, 240 \mathrm{~s}, 270 \mathrm{~s}, 300 \mathrm{~s}, 330 \mathrm{~s}$ and $360 \mathrm{~s}$ Slika 10. Rendgenske snimke uzoraka kocaka manjih stranica $(20 \mathrm{~mm})$ nakon pirolize pri $500{ }^{\circ} \mathrm{C}$; slijeva nadesno: nakon $60 \mathrm{~s}, 120 \mathrm{~s}, 180 \mathrm{~s}, 210 \mathrm{~s}, 240 \mathrm{~s}, 270 \mathrm{~s}, 300 \mathrm{~s}, 330 \mathrm{~s} \mathrm{i}$ $360 \mathrm{~s}$ 


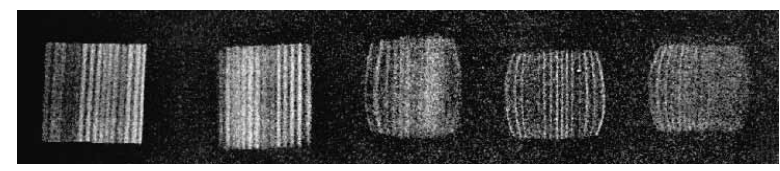

Figure 11 Radiographic images of perpendicular parallelepipeds with approximately $20 \times 20 \times 5 \mathrm{~mm}$, after pyrolysis at $500{ }^{\circ} \mathrm{C}$. From left to right: $30 \mathrm{~s}, 60 \mathrm{~s}, 90 \mathrm{~s}, 120 \mathrm{~s}$ and $150 \mathrm{~s}$ Slika 11. Rendgenske snimke okomitih paralelepipeda (približno $20 \times 20 \times 5 \mathrm{~mm}$ ) nakon pirolize pri $500{ }^{\circ} \mathrm{C}$; slijeva nadesno: nakon $30 \mathrm{~s}, 60 \mathrm{~s}, 90 \mathrm{~s}, 120 \mathrm{~s}$ i $150 \mathrm{~s}$

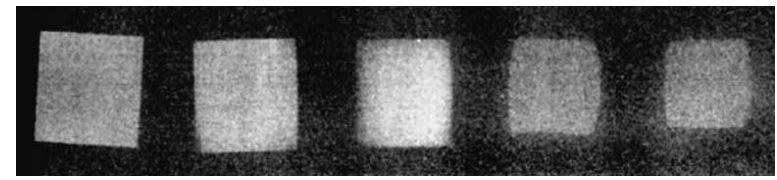

Figure 12 Radiographic images of parallel parallelepipeds with approximately $20 \times 20 \times 5 \mathrm{~mm}$, after pyrolysis at $500{ }^{\circ} \mathrm{C}$. From left to right: $30 \mathrm{~s}, 60 \mathrm{~s}, 90 \mathrm{~s}, 120 \mathrm{~s}$ and $150 \mathrm{~s}$

Slika 12. Rendgenske snimke paralelnih paralelepipeda (približno $20 \times 20 \times 5 \mathrm{~mm}$ ) nakon pirolize pri $500^{\circ} \mathrm{C}$; slijeva nadesno: nakon 30 s, 60 s, 90 s, 120 s i 150 s

By analysing Figure 13, it can be noted that the biggest diameter is perpendicular to the heat source, and corresponds to the darkest area in the samples. This happens because the highest volume loss takes place in the direction of the heat transfer, which corresponds to the smallest diameter.

\section{DISCUSSION \\ 4. RASPRAVA}

The smaller the samples, the bigger was the loss of mass. The mass decrease was also more significant for the samples cut perpendicular to the growth direction, meaning it was easier for the moisture and volatiles to be released in these samples than in the ones cut parallel to the grain. For density variations, a similar situation can be observed, with the exception of the short cylinder sample pyrolysed for $30 \mathrm{~s}$, whose density increased.

When it comes to volume, it would not always decrease. Due to the release of the volatile matter, the samples would shrink, but also stretch in the direction of release, which would sometimes increase their final value. It is worth noticing, however, that this fluctuation is only visible for the samples of smaller size. Once again, this was more noticeable for the perpendicular parallelepipeds, meaning that the gas release and its consequence on the sample's geometry were more intense for them. This situation was also noticed by Ronewicz et al. (2016), who considered it a consequence of the pressure of released volatiles. However, this might also be a by-product of incorrect measurements, since once the shape became irregular, the biggest dimension possible would be taken, which might mislead to bigger volumes than is actually true.

It is acceptable to assume that the mass of wood chips will also decrease with the pyrolysis residence time. Since wood chips have a smaller and more irregular form than the samples used, it is likely that the

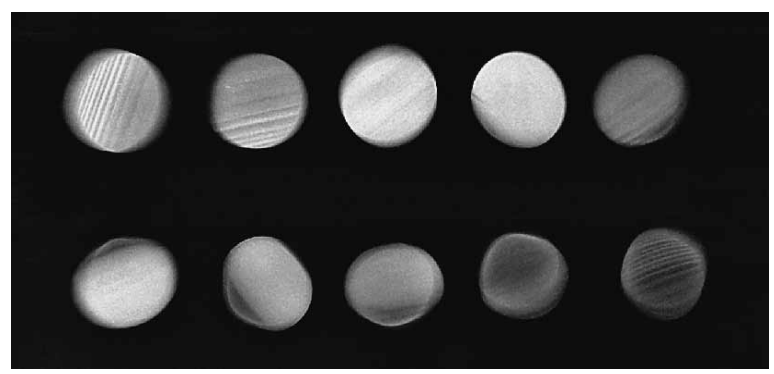

Figure 13 Radiographic images of cylindrical samples with approximately $27 \mathrm{~mm}$ of diameter and $35 \mathrm{~mm}$ height, after pyrolysis at $500{ }^{\circ} \mathrm{C}$. From left to right and top to bottom: 60 s, $120 \mathrm{~s}, 180 \mathrm{~s}, 240 \mathrm{~s}, 300 \mathrm{~s}, 360 \mathrm{~s}, 420 \mathrm{~s}, 480 \mathrm{~s}, 540 \mathrm{~s}$ and $600 \mathrm{~s}$

Slika 13. Rendgenske snimke valjkastih uzoraka približnog promjera $27 \mathrm{~mm}$ i visine $35 \mathrm{~mm}$ nakon pirolize pri $500{ }^{\circ} \mathrm{C}$; slijeva nadesno i odozgo prema dolje: nakon $60 \mathrm{~s}, 120 \mathrm{~s}$, 180 s, 240 s, 300 s, 360 s, 420 s, 480 s, 540 s i 600 s

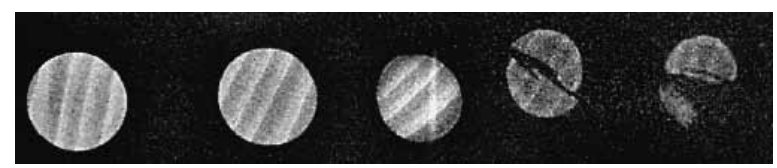

Figure 14 Radiographic images for cylindrical samples with approximately $20 \mathrm{~mm}$ of diameter and $5 \mathrm{~mm}$ height, after pyrolysis at $500{ }^{\circ} \mathrm{C}$. From left to right: $30 \mathrm{~s}, 60 \mathrm{~s}, 90 \mathrm{~s}, 120 \mathrm{~s}$ and $150 \mathrm{~s}$

Slika 14. Rendgenske snimke valjkastih uzoraka približnog promjera $20 \mathrm{~mm}$ i visine $5 \mathrm{~mm}$ nakon pirolize pri $500{ }^{\circ} \mathrm{C}$; slijeva nadesno: nakon $30 \mathrm{~s}, 60 \mathrm{~s}, 90 \mathrm{~s}, 120 \mathrm{~s}$ i $150 \mathrm{~s}$

volume will vary in a more uncertain way, leading to possible volume increases, as was the case with parallelepipedal samples, or even to density increases, just as with the first short cylindrical sample.

When analysing the mass variation with time, it is possible to see that the turning point for the smaller cubes is around $240 \mathrm{~s}$, just as in the thermogravimetric analysis. This indicates that the heating rate for these samples was close to $100 \mathrm{~K} / \mathrm{min}$. For the larger samples, the turning point happens at higher residence times, as expected. However, it was surprising to notice that it took less time for the smaller samples than for the TGA, meaning that heating rates were higher for the first ones. In fact, since the turning point is around $120 \mathrm{~s}$, it is acceptable to assume that the heating rate should be around $200 \mathrm{~K} / \mathrm{min}$ for these cases.

The heat transfer is delayed due to the release of volatiles from within the sample. However, the situation changes when it comes to the smaller samples, which have a significantly reduced height in comparison to the base area. These proportions facilitate the release of gases in the height direction, which increases the heat transfer in other directions. This proposal is supported by differences between the perpendicular and parallel parallelepipeds. In the first ones, the gas release is easier, and indeed the mass and density variations have always been more accentuated for perpendicular than for parallel parallelepipeds.

For the large samples, a flat zone between the two main decreases in the mass ratio can be found. The two 
most accentuated slopes correspond to the degradation of hemicellulose and cellulose, respectively. This flat zone cannot be observed in the smaller samples nor in the TGA, which means that it is a by-product of the more difficult heat transfer due to the sample size and shape.

In the X-ray images of the small and large cubes (Figures 9 and 10), a lighter circle can be seen for 300 $\mathrm{s}$ and $720 \mathrm{~s}$, respectively. Once again, this indicates the delayed heat transfer due to the gases released out. It is to be noticed that such density contrast cannot be seen in the parallelepipedal samples, which supports the hypothesis that their structure and increased surface area per mass facilitate the gas release, improving the heating rate.

The subject has not yet been sufficiently explored. Particularly noteworthy is the paper (Dhanarathinam and Kolar, 2013), which also deals with the use of radiography in the analysis of pyrolysis of a single particle. The paper confirms the possibility of using $\mathrm{X}$-rays to analyse the ratio of wood particle decomposition.

\section{CONCLUSION 5. ZAKLJUČAK}

The mass, volume and shape of the sample have a strong influence on the pyrolysis rate. Overall, the higher the initial mass and volume, the lower is the pyrolysis heating rate, and, therefore, the lower is the mass and volume decrease. Obtaining various products depending on the process parameters is confirmed by the work of other authors (Basu, 2010).

Testing different shapes and sizes gives a diverse range of heating rates, and therefore it can be taken as a good approximation of a real case scenario, in which each particle has its own characteristics.

It is possible to establish a bridge between the $\mathrm{X}$ ray and the thermogravimetric analysis results for larger cubic samples, since the appearance of the circle indicates the turning point after hemicellulose and cellulose decomposition has occurred.

\section{Acknowledgments - Zahvala}

We would like to acknowledge Marek Klein and Aleksandra Sadzińska for assisting in the Thermogravimetric Analysis.

\section{REFERENCES}

\section{LITERATURA}

1. Basu, P., 2010: Biomass Gasification and Pyrolysis: Practical Design and Theory (vol. 1). Oxford, Elsevier.

2. Czajczyńska, D.; Anguilano, L.; Ghazal, H.; Krzyżyńska, R.; Reynolds, A. J.; Spencer, N.; Jouhara, H., 2017: Potential of pyrolysis processes in the waste management sector. Thermal science and engineering progress, 3 : 171-197. https://doi.org/10.1016/j.tsep.2017.06.003.

3. Demirbas, M. F., 2010: Characterization of bio-oils from spruce wood (Picea orientalis L.) via pyrolysis. Energy Sources, Part A: Recovery, Utilization, and Environmental Effects, 32 (10): 909-916. https://doi.org//10.1080/15567030903059970.

4. Dhanarathinam, R. S.; Kolar, A. K., 2013: Visualization and characterization of thermo-physical behaviour of wood during devolatilization in a hot fluidized bed using $\mathrm{X}$-ray radiography technique. Fuel, 112: 208-223. https://doi.org/10.1016/j.fuel.2013.04.082.

5. Erlich, C.; Fransson, T. H.; 2011: Downdraft gasification of pellets made of wood, palm-oil residues respective bagasse: experimental study. Applied Energy, 88 (3): 899908. https://doi.org/10.1016/j.apenergy.2010.08.028.

6. Lu, P.; Huang, Q.; Bourtsalas, A. T.; Chi, Y.; Yan, J., 2018: Synergistic effects on char and oil produced by the co-pyrolysis of pine wood, polyethylene and polyvinyl chloride. Fuel, 230: 359-367. https://doi.org/10.1016/j.fuel.2018.05.072.

7. Pham, X. H.; Piriou, B.; Salvador, S.; Valette, J.; Van de Steene, L., 2018: Oxidative pyrolysis of pine wood, wheat straw and miscanthus pellets in a fixed bed. Fuel Processing Technology, 178: 226-235. https://doi.org/10.1016/j.fuproc.2018.05.029.

8. Ronewicz, K.; Kluska, J.; Heda, Ł.; Kardaś, D., 2017: Chemical and Physical Properties of Pine Wood during Pyrolysis. Drvna industrija, 68 (1): 29-36. https://doi.org/10.5552/drind.2017.1617.

9. Shi, X.; Wang, J., 2014: A comparative investigation into the formation behaviours of char, liquids and gases during pyrolysis of pinewood and lignocellulosic components. Bioresource technology, 170: 262-269. https://doi.org/10.1016/j.biortech.2014.07.110.

\section{Corresponding address:}

PAWEŁ KAZIMIERSKI, M. Sc. Eng.

Institute of Fluid Flow Machinery

Polish Academy of Sciences

Fiszera 14, 80-231 Gdańsk, POLAND

e-mail: pkazimierski@imp.gda.pl 